\title{
'MAGYARS AND VIKINGS IN THE SAME BOAT'. Public Archaeology and Experimental Re-Enactment in Hungary
}

\section{Csete Katona}

Hungarian Archaeology Vol. 8 (2019), Issue 4, pp. 46-50. https://doi.org/10.36338/ha.2019.4.1

A significant segment of public archaeology is connected to re-enacters who perform experiments thought to be 'authentic', i. e. representing the historical past as accurately as possible. These undertakings can rarely go beyond the reconstruction of elements of material culture and hardly challenge historical conceptions. Nevertheless, they are intriguing from a modern cultural point of view as representations of cultural heritage. The present piece concerns with such experiments carried out by Hungarian 'Viking're-enacters.

Viking re-enactment is popular all around the globe where countries can connect to a (global) Viking heritage of the late 8th to the mid-11th century, commonly known as the Viking Age. In the light of this, it is not evident for first glance why does interest among re-enacters develop towards Vikings in Hungary, a country with apparently no, or rather marginal relation to early medieval Scandinavian history, and where general public interest concerning the ancient past of the nation in a steppe nomadic milieu is dominating the re-enactor scene. Hungarian medieval re-enacters, however, started to include into their horizon the contemporaries of the Magyars as well, namely the Scandinavian Vikings, who were active participants in the history of Eastern Europe, usually known there by historical documents as the Rus'.

The 'Eastern Viking' or Rus' heritage interestingly entered into a fusion with the Magyar past in the re-enacter world. This is reflected in two public archaeological experiments undertaken by Hungarian re-enacters; the construction of a public open-air-museum and a 'Viking' boat tour. It has also to be noted, however, that there are Viking re-enacters even in non-European countries like New Zealand, Peru or South Africa, although these are mostly marginal groups and their existence is better explained by a general globalized fascination towards the Vikings, which similarly to Japanese samurais, or Caribbean pirates, can develop everywhere.

\section{THE EMESE PARK AND THE VIKINGS}

Viking and Magyar re-enactment co-exist in one of the open-air museums, the Emese Park, located at Szigethalom not far from Budapest. The park already signals its double Hungarian-European bonding with the name itself, which refers to the legendary mother of the ancient Hungarians; Emese, whilst it is also an abbreviation for 'European Medieval Settlement' (E-Me-Se). ${ }^{1}$ The museum village — as it is called on the website - is a fictional reproduction of a 10th-11th-century (or in certain details even later) Hungarian settlement with a gate, earthwork fortifications, halls, stables and other buildings related to animal husbandry or craftworks. Built on the place of a former military base, it has no connection to any archaeological site. As similar institutions, the park is a product of public archaeology, which hosts events, guided tours and offers various activities to guests, whilst claiming authenticity when spreading knowledge in an entertaining way.

However, the park has an eclectic (rather than a clear scientific) agenda. It is apparent, for instance, that in the park, elements of a Viking settlement can also be found. There used to be a small Viking stronghold in the park, Tyrkerborg, named after the character Tyrker featuring in the Icelandic Gronlendinga saga, who is believed to be a Magyar nomad travelling with the Norsemen to America around the millennium (PIVÁNy, 1903). No matter how this identification is valid from a scholarly point of view, according to popular culture it is still part of the fragmentary evidence which connects Hungarians with Vikings. One of the emblematic figures of Hungarian re-enactments and director of the Emese Park, Attila Magyar,

http://www.emesepark.hu/html/magunkrol.html [Accessed: 09. 05. 2018] 
also bears the nickname, Tyrker. Although Attila is devoted to represent and reconstruct the ancient Hungarian past, he acknowledges that Vikings as contemporaries are essential parts of this heritage. As being one of the first among Hungarian re-enacters, he recalls the appearance of the first 'Hungarian Vikings' around the early years of the movement in the 1990s when the 'Hungarian conquest period' re-enacters realized the need for potential allies and enemies in order to reconstruct battles. Before the construction of the Emese Park, in 1999, they already built a Viking longhouse in an archaeological park (EzüstFa Várudvar) in Budapest. Attila organizes many events connected to Vikings such as various annual gatherings at Szigethalom, including a so-called 'Winter chasing' at the end of February, boat tours, and the peculiar 'Vikings and Magyars in St. Stephen's court' meeting ${ }^{2}$ (Fig. 1).

In 2007, the Norwegian ambassador to Vienna, Bante Angell-Hansen, and Iceland's honorary consul in Hungary, Ferenc Utassy, also visited the Emese Park to symbolically erect a carved column at the place of the Viking fort and a future Viking longhouse (CSORDÁs, 2007). The presence of today's representatives of the Nordic countries vividly illustrates the park's decisive relation to the global Viking heritage. This is further testified by visiting groups of re-enactors from the Nordic countries in the last years. ${ }^{3}$

For including the Vikings in medieval Hungarian

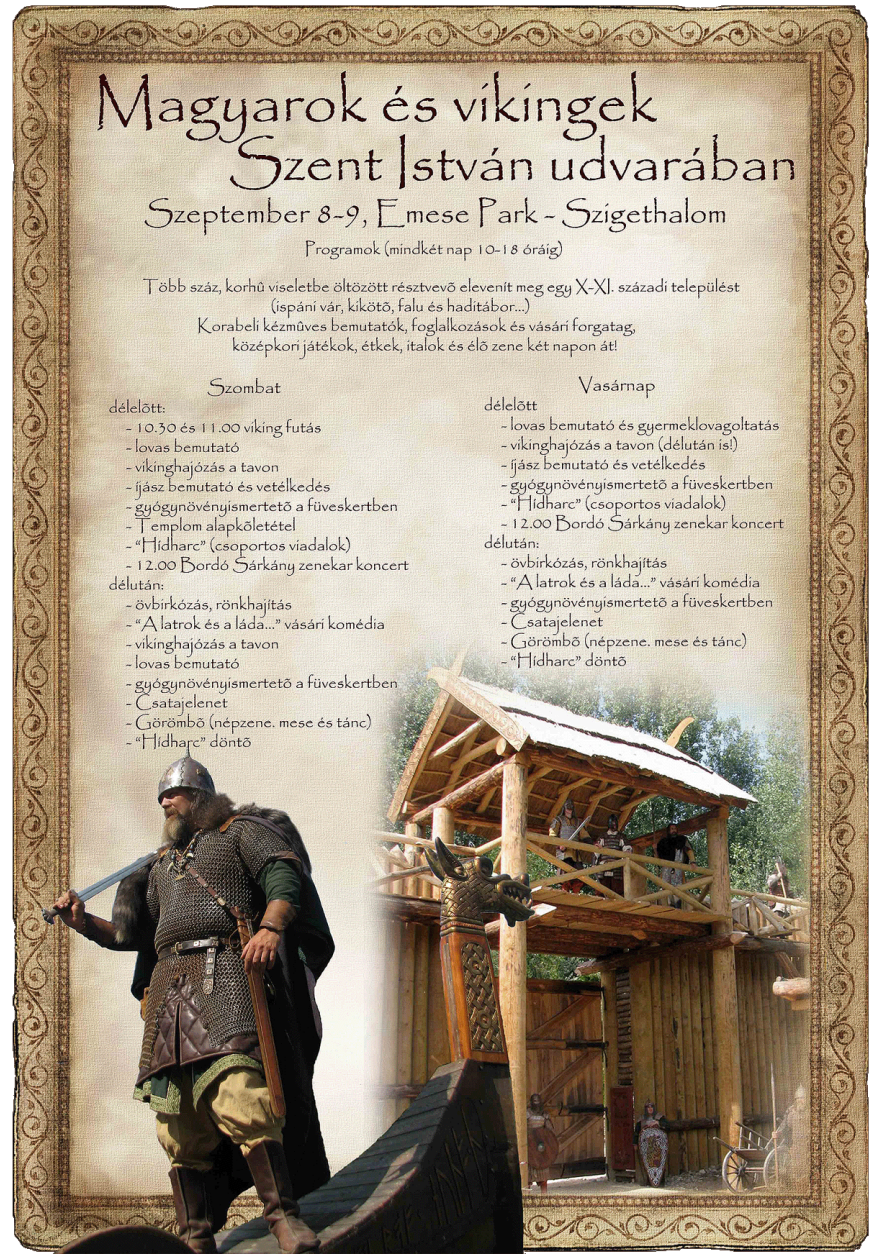

Fig. 1. Re-enactment poster advertising the event 'Hungarians and Vikings in Saint Stephen's court'.

(Source: http://www.nemzetibulvar.hu/wp-content/ uploads/2012/09/emesepark2012.gif

[Accessed 12 May, 2018]) cultural heritage, re-enacters make use of arguments formulated by modern researchers on the involvement of Rus warriors in the bodyguard of the first Hungarian rulers, Grand Prince Géza (972-997) and King Saint Stephen I (1000-1038) (cf. Katona, 2017a).

\section{VIKING BOATS IN HUNGARY}

The other theme connecting the Hungarian case with the Scandinavian experience is a small boat experiment. In the Scandinavian countries there is a strong tradition of building Viking ship replicas for scientific and non-scientific reasons alike. In Hungary this is hardly the case and thus it feels remarkable that in the Emese Park, an inner lake, hosting boat tours to tourists on three replicated Viking ships, is also present (Fig. 2). The mixture of Viking-Magyar identity is further reflected in two of the ships' names: Toportyán, referring to a Hungarian species of coyote, and Kalamóna, a powerful dragon mastering the wind in Hungarian mythology. Thus, the two Viking ships possess names culturally linked to Hungarian tradition.

The two mentioned boats ( 7 and 11 meters long) participated in a smaller experiment when tested on a tour along the Csepel Island on the Danube in 2017. The boat tour lasted three days and completed $120 \mathrm{~km}$ on the river, half of which was taken in headwind and upstream. The experiment, however, was testing the crews' capacity and equipment rather than any scientific theories. Although the smaller Viking ship was

\footnotetext{
Attila Magyar, personal communication, 2018.

Attila Magyar, personal communication, 2018.
} 
dragged on land on the way back to the park, which could be regarded as testing the transportability of Viking ships on terrestrial routes, the larger onemeasuring one ton-was hardly pulled up and put on a car which hauled it to the river and back. The experiment did not set out any scientific research questions to test, and no professional scholars (archaeologists or historians) were involved in the undertaking. The main results of the 'Viking ship tour' were rather important to the re-enacters themselves as a measurement of the hardships of such a journey during rowing, eating on board, suffering from bad weather, constructing camps on the river shores and sleeping outside at night. ${ }^{4}$

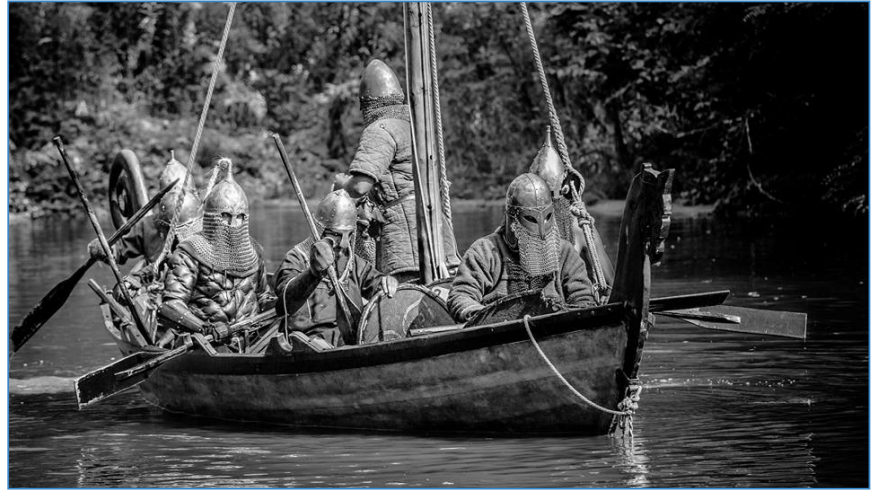

Fig. 2. Hungarian Vikings rowing the waters in Emese Park. (Source: http://www.emesepark.hu/foto/14-keptar/12006339 10518997981550981166011273298545322 n.jpg [Accessed 12 May, 2018])

Similar experiments, although in a more scholarly manner were conducted in Hungary by a group of Swedish scholars and experimenters in 1985. The so-called Krampmacken expedition sailed down the Eastern European rivers, taking the Hungarian Bodrog and Tisza rivers down to the Danube to prove that Vikings were indeed able to travel with their own (small) boats from Scandinavia to Constantinople (EDBERG, 2009). The journey is lesser known

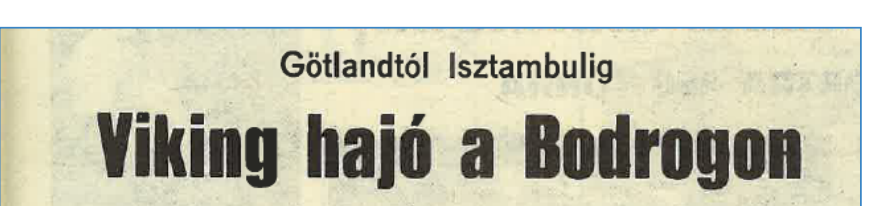

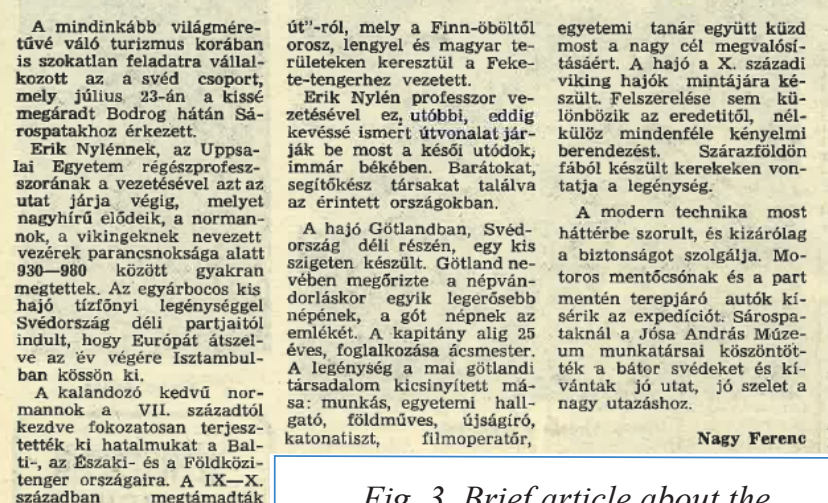
Angliát, Skóciát, lrországot, majd az írek átal a vII dot. $\mathrm{Az}$ izlandi normann telepesek Vorös Erik vezetése(a) Leif 1000 körüil Amerikél ajôzott. Eszak-Amerikába három telepet is létesitettel tek és hamar feledésbe meültek. A zsákmányszerzésért, rab ditások egy mormann ho Európa belseje. A hajózhat colyókon hatoltak be a szálenkedtek, raboltak, fosto gattak, rettegésben tartottál
a lakosságot. 885-886-ban tiz hónapon keresztül ostroták megtörni védói szivós elenállását. Kelet-Európában varjá nokat. Az orosz krónika megemiékeennek a ,varjágok-
tộl a görögökhoóz vezetố nag

Fig. 3. Brief article about the Krampmacken expedition in a Hungarian newspaper. (Source: NAGY 1985, p. 4.) by the Hungarian scholarly audience in spite of that the workers of the Jósa András Museum greeted the 'Swedish Vikings' on the shores of the River Bodrog (Fig. 3). The experiment was started from the river Vistula and all in all took 131 days to complete, to which it should be added that the boat was pulled on land by a cart for 658 kilometres (NYLÉN, 1987). Although the route taken by the Krampmacken is unattested in historical records and is unlikely to have been extensively used by the Vikings, the experiment provided a historically possible alternative to our existing knowledge on utilized Viking waterways in Eastern Europe (KATONA, 2017b). Related attempts with the involvement of experts is so far lacking in the case of Viking re-enactment and experimental archaeology in Hungary, which are in initial phases concerning co-operation with academic research. Although notable achievements in this regard abroad also come from the side of scholars rather than the re-enactors (Price \& Mortimer, 2014; Gardela, 2016), Hungarian re-enactment is so far confined to test steppe nomadic warfare techniques with limited results (IGAz, 2007). Despite being a more scientifically articulated mission, the Swedish expedition is largely unknown in Hungary both in public and scientific circles. In contrast, ships of the Emese Park even feature on a lease in the popular British TV series, The Last Kingdom, pointing out the importance of such sites in influencing the public image of the historical past.

\footnotetext{
Csepel-sziget kerülö vikinghajózás, 2017. március 17-19. [Viking voyage around the Csepel Island, 17-19 March 2017] http://members.upc.hu/venczel.gabor1/hajotura.jpg. [Accessed: 24. 04. 2018]
} 
Csete Katona • 'Magyars And Vikings in the Same Boat'. Public Archaeology and Experimental Re-Enactment in Hungary

\section{RECOMMENDED READS}

Andersson, T., 2000.

Krampmacken - a modern Viking ship reconstruction. Viking Heritage Magazine 2, pp. 5, 13.

KobiaŁKa, D., 2013.

The mask(s) and transformers of historical re-enactment. Material culture and contemporary vikings. Current Swedish Archaeology, 21, pp. 141-161.

Katona, C., 2018.

Co-operation between the Viking Rus' and the Turkic nomads of the steppe in the ninth-eleventh centuries. MA Thesis, Central European University.

ZiMONYI, I., 2015.

Muslim Sources on the Magyars in the Second Half of the 9th Century. The Magyar Chapter of the Jayhāni Tradition. Leiden: Brill. doi: https://doi.org/10.1163/9789004306110.

\section{BIBLIOGRAPHY}

CSORDÁs, L., 2007.

Viking kaland Szigethalmon [Viking adventure in Szigethalom]. Népszabadság, 2 July, 2007. [Online] Source: http://nol.hu/archivum/archiv-452344-259234. [Accessed 10 May 2018]

EDBERG, R., 2009.

Experimental "Viking voyages" on Eastern European rivers, 1983-2006. Situne Dei 2009. Arsskrift för Sigtunaforskning utgiven av Sigtuna Museum / Annual of Sigtuna Research Published by Sigtuna Museum, pp. 35-46.

GARDEŁA, L., 2016.

Vikings Reborn: The origins and development of Early Medieval Viking re-enactment in Poland. Sprawozdania Archeologiczne, 68, pp. 165-182. https://doi.org/10.23858/sa68.2016.009.

IGAZ, L., 2007.

Kísérleti régészet Magyarországon és külföldön: néhány példa különböző történeti korszakok kísérleti régészeti úton történő „életre keltésére”. Megjegyzések az Árpád-kor harcászatának a kísérleti régészet módszereivel történő rekonstrukciós kérdéseihez [Experimental archaeology in Hungary and abroad: Examples for 'reenactment' of different historical periods through the means of experimental archaeology. Notes on the questions of reconstructing Arpad Period warfare with experimental archaeological methods]. Aetas, 22(4), pp. 161-169.

Katona, Cs., 2017a.

Vikings in Hungary? The theory of the Varangian-Rus bodyguard of the first Hungarian rulers. Viking and Medieval Scandinavia, 17, pp. 23-60. https://doi.org/10.1484/j.vms.5.114350.

Katona, Cs., 2017 b.

Rusz-varég kereskedelmi útvonalak a IX-X. századi Kelet-Európában és a Kárpát-medencében [RusVarangian trade routes in the 9th-10th century in Eastern Europe and the Carpathian Basin]. Jósa András Múzeum Évkönyve, 59(2), pp. 233-252. 
Csete Katona • 'Magyars And Vikings in the Same Boat'. Public Archaeology and Experimental Re-Enactment in Hungary

NAGY, F., 1985.

Götlandtól Isztambulig. Viking hajó a Bodrogon [From Götland to Istanbul. A Viking ship on the Bodrog river]. Kelet-Magyarország, 188, p. 4.

NYLÉN, E., 1987.

Vikingaskepp mot Miklagård. Krampmacken i Österled [Viking ship set for Micklagård. Krampmacken journeying eastward]. Stockholm: Carlsson.

PivÁny, J., 1903.

Magyar volt-e a Heimskringla Tyrker-je? [Was Tyrker in Heimskringla a Magyar?] Századok, 43(7), pp. 571-577.

Price, N. \& Mortimer, P., 2014.

An eye for Odin? Divine role-playing in the age of Sutton Hoo. European Journal of Archaeology, 17(3), pp. 517-538. https://doi.org/10.1179/1461957113y.0000000050.

SINDBÆK, S. M., 2013.

All in the same boat. The Vikings as European and global heritage. In: D. Callebaut, J. Mařík \& J. MaříkovaKubková, eds., Heritage Reinvents Europe. Proceedings of the International Conference, Ename, Belgium, 17-19 March, 2011. EAC Occasional Papers 7. Budapest: Aduprint, pp. 81-87. 